\title{
Hybridization Experiments with Deoxyribonucleic Acid from Ureaplasma urealyticum Serovars I to VIII
}

\author{
CLAUS CHRISTIANSEN, F. T. BLACK, AND E. A. FREUNDT \\ Institute of Medical Microbiology, University of Aarhus, DK-8000 Aarhus C, Denmark
}

\begin{abstract}
Nucleic acid hybridization experiments performed with deoxyribonucleic acid from serovars (serotypes) I to VIII of Ureaplasma urealyticum revealed a clustering of the analyzed strains into two major groups. One cluster included serovars I, III, and VI and the other included serovars II, IV, V, VII, and VIII, the two groups being distinguished at the 40 to $60 \%$ homology level. No consistent correlation could be demonstrated between the nucleic acid homology data presented here and the heterologous serological relationships known to exist between different serovars of $U$. urealyticum. On the other hand, agreement was found between clusterings according to deoxyribonucleic acid homologies and recently published observations made by polyacrylamide gel electrophoresis methods.
\end{abstract}

The problem of the taxonomic status of the $\mathrm{T}$-mycoplasmas has been at issue almost since they were first recognized as a separate entity within the mycoplasmas (15). In 1974, the Tmycoplasmas isolated from humans and other vertebrates were classified in a new genus, Ureaplasma, of the family Mycoplasmataceae (16). A single species, Ureaplasma urealyticum, was proposed for T-mycoplasmas of human source; it contains the eight serovars (serotypes) (I through VIII) defined by Black (2, 5; F. T. Black, Ph.D. thesis, University of Aarhus, Aarhus, Denmark, 1974) on the basis of growth inhibition, metabolism inhibition, indirect immunofluorescence, and indirect hemagglutination tests. A ninth serovar, defined by a modified metabolism inhibition test, was proposed recently (13). In the case of the genus Mycoplasma, distinct serovars would have been recognized as separate species, but Shepard et al. (16) abided by a recommendation made by the International Committee on Systematic Bacteriology Subcommittee on the Taxonomy of Mycoplasmatales (10) and classified the eight serovars of Ureaplasma in one species.

Although some of the eight (nine) serovars included in $U$. urealyticum are serologically quite distinct, a variable degree of cross-reactivity has been observed among others $(2,3,5,8$, 11, 13; Black, Ph.D. thesis, 1974). These reactions are mostly in the form of one-way crossings.

The values reported for the guanine-plus-cytosine contents of the deoxyribonucleic acids (DNAs) of the eight serovars are very close to each other: 26.9 to $28.0 \mathrm{~mol} \%$ by buoyant density (4) and 27.6 to $28.5 \mathrm{~mol} \%$ by $T_{m}(1,4)$. The genome size is about $4.5 \times 10^{8}$ daltons (4).
The purpose of this study was to determine the degree of DNA homology between $U$. urealyticum serovars I through VIII and to determine if there is any correlation between a possible clustering according to nucleic acid hybridization levels and data obtained in earlier studies by serology and polyacrylamide gel electrophoresis (PAGE) methods.

\section{MATERIALS AND METHODS}

Ureaplasma strains. Reference strains 7, 23, 27, $58,354, \mathrm{Pi}, \mathrm{Co}$, and $\mathrm{T}-960$, representing serovars $\mathrm{I}$ through VIII of $U$. urealyticum (with strain T-960 = serovar VIII as the type), were used (16).

Cultivation and harvest of organisms. The medium was a modified Shepard medium (3) supplemented with $0.04 \%$ urea. For DNA labeling, $2.5 \mathrm{mCi}$ of [methyl ${ }^{3} \mathrm{H}$ ]thymidine (Amersham Radiochemical Center; specific activity, $20 \mathrm{Ci} / \mathrm{mmol}$ ) was added to the culture at the time of inoculation. The urea plasmas were grown by inoculating 5 liters of medium with a $300-\mathrm{ml}$ culture. After incubation for $12 \mathrm{~h}$ at $37^{\circ} \mathrm{C}$, the cell density was $1 \times 10^{7}$ to $5 \times 10^{7}$ colony-forming units $/ \mathrm{ml}$. Cells were collected by centrifugation at $27,000 \times g$ for $1 \mathrm{~h}$, and the pellets were suspended in $2 \mathrm{ml}$ of saline-ethylenediaminetetraacetic acid (EDTA) (0.1 M NaCl-0.01 M disodium EDTA, pH 8.0).

DNA extraction and purification. The suspended cells were lysed by the addition of sodium dodecyl sulfate to a concentration of $1 \%$ followed by incubation at $60^{\circ} \mathrm{C}$ for $10 \mathrm{~min}$. After deproteinization by phenol and extensive dialysis against $0.1 \mathrm{M}$ tris (hydroxymethyl)aminomethane-hydrochloride, pH 7.5, 0.01 M EDTA, and $0.3 \mathrm{M} \mathrm{NaCl}$, the nucleic acids were precipitated with ethanol. The precipitate was redissolved in SSC $(0.15 \mathrm{M} \mathrm{NaCl}$ plus $0.05 \mathrm{M}$ trisodium citrate, $\mathrm{pH} \mathrm{7.0)}$ and digested with pancreatic $(50 \mathrm{U} / \mathrm{ml})$ and $T_{1}(10 \mathrm{U} / \mathrm{ml})$ ribonucleases for $30 \mathrm{~min}$ and by pronase $(0.1 \mathrm{mg} / \mathrm{ml})$ for $2 \mathrm{~h}$. The DNA was banded in a $\mathrm{CsCl}$ gradient with ethidium bromide, 
identified by the fluorescence, and collected by needle puncture. The final purification was by dialysis followed by ethanol precipitation. Spectrophotometry and spectrofluorometry were used for determination of DNA concentrations, and all preparations were analyzed by analytical $\mathrm{CsCl}$ gradients with Micrococcus luteus DNA as a marker. The buoyant densities obtained agreed with those previously reported (4).

DNA-DNA hybridization. DNA-DNA hybridization experiments were performed as described previously (6) by a membrane filter method. This method requires (with the available specific radioactivity) less DNA per measurement than does hybridization in solution followed by analysis of the hybrids on hydroxylapatite or with S1 endonuclease. In our hands and with a variety of bacterial and mycoplasma DNAs, the three methods give identical results (C. Christiansen, unpublished data).

One-half-microgram amounts of alkaline-denatured DNA were filtered through nitrocellulose filters (Millipore type HAWP, $25 \mathrm{~mm}$ ). The filtering buffer was $1 \mathrm{M} \mathrm{NaCl}, 0.005 \mathrm{M} \mathrm{MgCl}_{2}$, and $0.05 \mathrm{M}$ tris (hydroxymethyl) aminomethane-hydrochloride, $\mathrm{pH}$ 7.5. After heat fixation for $2 \mathrm{~h}$ at $80^{\circ} \mathrm{C}$ in vacuum, the filters were incubated for $2 \mathrm{~h}$ in Denhardt medium (7). Hybridization was in $2 \times \mathrm{SSC}$ with 0.3 to $0.7 \mu \mathrm{g}$ of labeled DNA added per filter. The specific activity of labeled DNA was 10,000 to $30,000 \mathrm{cpm} / \mu \mathrm{g}$, and 0.1 to $0.25 \mu \mathrm{g}$ of radioactive DNA per filter was bound in homologous reactions.

\section{RESULTS AND DISCUSSION}

Table 1 presents the results of the DNA-DNA reactions. Each reaction is expressed as the hybrid yield in percentage of the homologous reaction, and the figures given are the average of two to seven experiments involving, in all instances, the results of at least one double-cross experiment (i.e., radioactive $a$ versus $b$, and radioactive $b$ versus $a$ ). The hybridization was in most experiments measured on two equivalent filters, and in some experiments on three or four. Equivalent filters differed, in terms of cpm bound, by 0 to $5 \%$ of the total. Occasionally larger variations were seen. The standard error on the averages of the hybridization reactions were 2 to $7 \%$. The homologous reactions showed binding of 0.1 to $0.25 \mu \mathrm{g}$ of DNA, equivalent to
20 to $50 \%$ of the DNA on the filters. This indicates that leaking of DNA from the filters occurred only to a very small extent. Control experiments with radioactive DNA showed an 80 to $100 \%$ retention of radioactivity during the hybridization procedure.

According to the hybridization percentages shown in Table 1, there is a clustering of the analyzed specimens into two groups. One cluster included serovars I, III, and VI; the other includes serovars II, IV, V, VII, and VIII. Whereas about 40 to $60 \%$ DNA homology was found between the two clusters, more than $90 \%$ homology existed between the specimens within the first cluster. The second cluster is less homogeneous and possibly may be further divided into two subgroups containing serovars II, IV, and V and the serovars VII and VIII, respectively.

The high level of DNA homology demonstrated between samples from different serovars indicates that only very limited variation will be found within each serovar. It follows that primary testing of DNA homology of any new serovar can be limited to one serovar from each of the two major groups.

The heterologous serological reactions between the different serovars of $U$. urealyticum observed to a varying extent by different authors $(2,3,5,8,11,13$; Black, Ph.D. thesis, 1974) are extremely complex, and there is hardly any consistent correlation between serology and nucleic acid homology data. It should be noted, however, that one-way cross-reactions demonstrable by the highly specific growth inhibition and indirect immunofluorescence tests are found only between serovars within each of the two major subgroups defined by the nucleic acid homology level $(2,3,5$; Black, Ph.D. thesis, 1974). In the experiments of Black (2, 3; Ph.D. thesis, 1974) and Ford (8), the same holds true for the metabolism inhibition test when exception is made for cross-reactions in insignificantly low titers. However, a few one-way cross-reactions to relatively high titers by metabolism inhibition have been reported between geneti-

TABLE 1. Hybrid yields in percentage of homologous reactions with DNA-DNA hybrids of U. urealyticum serovars

\begin{tabular}{rrrrrrrrrr}
\hline Serovar & Strain & \multicolumn{1}{c}{7} & 27 & Pi & 23 & 58 & 354 & Co & T-960 \\
\hline I & 7 & 100 & & & & & & & \\
III & 27 & 91 & 100 & & & & & & \\
VI & $\mathrm{Pi}$ & 92 & 102 & 100 & & & & & \\
II & 23 & 52 & 56 & 50 & 100 & & & & \\
IV & 58 & 46 & 55 & 38 & 93 & 100 & 100 & & \\
V & 354 & 49 & 52 & 48 & 85 & 97 & 100 & \\
VII & Co & 38 & 49 & 60 & 83 & 70 & 92 & 100 & \\
VIII & T-960 & 52 & 49 & 52 & 82 & 69 & 86 & 93 & 100 \\
\hline
\end{tabular}


cally more distantly related serovars by others $(11,13)$. A certain degree of cross-reactivity between such serovars is demonstrable also by the less specific indirect hemagglutination test $(2,5$; Black, Ph.D. thesis, 1974). The particularly close relationship found by all of the four serological methods between serovars II and V $(2,3,5,8$, 11; Black, Ph.D. thesis, 1974) is perfectly in line with the $85 \%$ relatedness value of the DNAs from these two types.

Comparative studies $(5,9,12,14$; J. Texier, C. Mouches, J. M. Bové, D. Taylor-Robinson, C. Howard, N. Gourlay, and J. Latrille, Abstr. 3rd Conf. Int. Org. Mycoplasmol., abstr. no. 57, 1980) of the different serovars of $U$. urealyticum by PAGE have revealed a fundamental, strong similarity in the protein patterns of all strains tested so far, although most serovars possess at least one specific protein band in major amounts. Sayed and Kenny (14), when testing the first eight serovars by SDS-PAGE, made the additional observation that some prominent polypeptides are located in only certain serovars. Thus, a polypeptide of 51,000 daltons was common to serovars II, IV, V, and VIII, whereas a 46,000-dalton polypeptide was found in serovars II, IV, V, VII, and VIII. Also, upon comparison of the serovars by isoelectric focusing, the representative strains of serovars II, IV, V, and VII were shown by Sayed and Kenny (14) to contain proteins which focused at $\mathrm{pH} 5.3$ and which were not seen in the remaining strains. Howard et al. (9), in a very recent study, detected a protein band that was shared by serovars II, IV, V, VII, and VIII but that was not found in serovars I, III, and VI.

The observation by Howard et al. (9) is in complete agreement with the subdivision of the eight serovars into two major groups on the basis of nucleic acid homology levels. A similar though less complete correlation is found between the results of the study of the polypeptide protein patterns of serovars I to VIII reported by Sayed and Kenny (14) and the observations reported in this paper.

The International Committee on Systematic Bacteriology Subcommittee on the Taxonomy of Mollicutes has expressed reservations toward the establishment of new Ureaplasma species (10; Subcommittee on the Taxonomy of Mollicutes, International Committee on Systematic Bacteriology, Minutes of meeting, submitted for publication) until a more detailed species concept has been developed for the genus. The recent evidence from PAGE analyses and the demonstration of differences in nucleic acid base homologies at the 40 to $60 \%$ level provide information which could justify a subdivision of the genus into at least two distinct species. Serological methods, however, point to only faint similarities between serovars, and it may be further argued that the similarities demonstrated between the PAGE protein patterns of the two major clusters are by far more conspicuous than the dissimilarities. Subdivision of the genus must therefore await a recommendation by the subcommittee on the criteria to be used for a subdivision.

\section{ACKNOWLEDGMENTS}

This work was supported by grants from the Danish Medical Research Council, Aarhus Universitets Forskningsfond, and the Fogh-Nielsen Foundation.

We thank Jørgen Andresen and Tove Faurholdt Jensen for excellent technical assistance.

\section{LTERATURE CITED}

1. Bak, A. L., and F. T. Black. 1968. DNA base composition of human T strain mycoplasmas. Nature (London) 219: 1044-1045.

2. Black, F. T. 1970. Serological methods for classification of human T mycoplasmas. Fifth Int. Congr. Infect. Dis. 1:407-411.

3. Black, F. T. 1973. Modifications of the growth inhibition test and its application to human T-mycoplasmas. Appl. Microbiol. 25:528-533.

4. Black, F. T., C. Christiansen, and G. Askaa. 1972. Genome size and base composition of deoxyribonucleic acid from eight human T-mycoplasmas. Int. J. Syst. Bacteriol. 22:241-242.

5. Black, F. T., and A. Krogsgaard-Jensen. 1974. Application of indirect immunofluorescence, indirect haemagglutination and polyacrylamide-gel electrophoresis to human T-mycoplasmas. Acta Pathol. Microbiol. Scand. Sect. B 82:345-353.

6. Christiansen, C., G. Askaa, E. A. Freundt, and R. F. Whitcomb. 1979. Nucleic acid hybridization experiments with Spiroplasma citri and the corn stunt and suckling mouse cataract spiroplasmas. Curr. Microbiol. 2:323-326.

7. Denhardt, D. T. 1966. A membrane-filter technique for the detection of complementary DNA. Biochem. Biophys. Res. Commun. 23:641-646.

8. Ford, D. K. 1967. Relationships between mycoplasma and the etiology of nongonococcal urethritis and Reiter's syndrome. Ann. N. Y. Acad. Sci. 143:501-504.

9. Howard, C. J., D. H. Pocock, and R. N. Gourlay. 1981. Polyacrylamide gel electrophoretic comparison of the polypeptides from ureaplasmas isolated from cattle and humans. Int. J. Syst. Bacteriol. 31:128-130.

10. International Committee on Systematic Bacteriology, Subcommittee on the Taxonomy of Mycoplasmatales. 1974. Minutes of meeting, 5 and 6 September 1973. Int. J. Syst. Bacteriol. 24:390-392.

11. Purcell, R. H., R. M. Chanock, and D. Taylor-Robinson. 1969. Serology of the mycoplasmas of man, p. 221264. In L. Hayflick (ed.), The Mycoplasmatales and Lphase of bacteria. Appleton-Century-Crofts, New York.

12. Razin, S., J. Valdesuso, R. H. Purcell, and R. M. Chanock. 1970. Electrophoretic analysis of cell proteins of T-strain mycoplasmas isolated from man. J. Bacteriol. 103:702-706.

13. Robertson, J. A., and G. W. Stemke. 1979. Modified metabolic inhibition test for serotyping strains of Ureaplasma urealyticum (T-strain mycoplasma). J. Clin. Microbiol. 9:673-676. 
14. Sayed, I. A., and G. E. Kenny. 1980 . Comparison of the proteins and polypeptides of the eight serotypes of Ureaplasma urealyticum by isoelectric focusing and sodium dodecyl sulfate-polyacrylamide gel electrophoresis. Int. J. Syst. Bacteriol. 30:33-41.

15. Shepard, M. C. 1956 . T-form colonies of pleuropneumo- nialike organisms. J. Bacteriol. 71:362-369.

16. Shepard, M. C., C. D. Lunceford, D. K. Ford, R. H. Purcell, D. Taylor-Robinson, S. Razin, and F. T. Black. 1974. Ureaplasma urealyticum gen. nov., sp. nov: proposed nomenclature for the human $\mathrm{T}$ ( $\mathrm{T}$ strain) mycoplasmas. Int. J. Syst. Bacteriol. 24:160-171. 